\title{
Az Audi Hungaria Motor Kft. hatása a helyi gazdasági és társadalmi folyamatokra
}

\author{
Audi Hungaria Motor Kft. in the local economy
}

\author{
CZAKÓ KATALIN
}

CZAKó Katalin: PhD-hallgató, Széchenyi István Egyetem, Regionális- és Gazdaságtudományi Doktori Iskola, Győr; ckatalin@sze.hu

KULCSSZAVAK: területi tőke, külföldi befektetés, területi gazdaságfejlesztés, vállalkozások

ABSZTRAKT: Egy terület gazdasági szerkezetének vizsgálatában és területi tőkéjének összetételében a magán- és állótőke mérése a területi hatások megfigyelése szempontjából fontos. Győr város fontos feladata a gazdaság történelmi múltra építő működésének fejlesztése. A tanulmány az Audi Hungaria Motor Kft. Győr város gazdasági környezetébe való beágyazódását foglalja össze. Kiemelem azokat a vállalati tulajdonságokat, melyek hatással vannak Győr életére, hangsúlyozom a vállalati adottságokat, az innovatív törekvéseket (logisztika, társadalmi felelősségvállalás). Fejezetenként tárgyalom a gazdasági környezet azon jelenségeit, folyamatait, melyek a vállalat jelenlétéből adódóan a városi és a nemzetgazdaságra jelentős hatással vannak. Ezek a regionális gazdaság számára fontos hatásmechanizmusokat képeznek, melyek szem előtt tartása fontos lehet a város hosszú távú területi fejlődésében. A tanulmány öt részre bontható. Az általános vállalati bemutatás után a letelepedési és az utóbbi évek terjeszkedési folyamatait kiemelve bemutatom a helyi munkaerőre gyakorolt hatásokat. Ezután a logisztikai folyamatok szabályait és a beszállítói hálózat szilárdságát vizsgálom, így körüljárom a helyi vállalkozásokra, különösen a beszállítói hálózatban működő helyi vállalkozásokra gyakorolt hatás kérdéskörét. A következő részek a város közvetlen gazdaságfejlesztő szerepvállalását, valamint a vállalat helyi gazdaságot és társadalmat érintő törekvéseit mutatják be.

Katalin CZAKÓ: PhD student, Doctoral School of Regional- and Economic Sciences, Széchenyi István University, Győr; ckatalin@sze.hu

KEYWORDS: territorial capital, foreign investment, regional development, entrepreneurialism

ABSTRACT: The role of foreign direct investment can be an important success factor for a region. In the overall constitution of a region's territorial capital, private, non-speculative capital and the networks of ownership associated with it are objectively quantifiable material goods that contribute to the measurability of a region's value. In the case of Györ, entrepreneurialism is strongly affected by foreign capital. This has visible and institutionalized results for this town and in its surroundings. The spatial aspects of these results are described and future development trajectories are sketched in this paper.

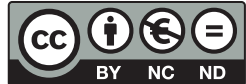


The high rate of foreign direct investment has an important impact. One such effect is the generation of intensive demand for a specialized workforce in the given region. There are several additional points worth analyzing. The paper describes the cooperation between Györ and Audi Hungaria Motor Kft. Further, it highlights the chief characteristics of the hosting region and those of the company, and how these characteristics impact on other stakeholders in the local economy.

The paper divides into five main sections. The first section deals with Audi Hungaria Motor Kft. The company's economic significance is analyzed, relevant developments in recent years are described, and the company's long-term plans for the town are sketched. In the second section, the paper briefly analyzes demographic data, especially information concerning the labour market in Györ and its surroundings. It also outlines Audi's expansion process. The principal conclusion of this discussion is that Audi needs an increasingly large, specialized workforce in a region where the share of active population is not significantly higher than in other Hungarian counties.

The third section offers a detailed picture of the company's logistical systems and subcontracting network. Audi manages logistics processes through a set of well-defined rules and routines. These are to be followed by every employee. Subcontracting is carefully regulated as well. Quality requirements imposed on suppliers are high. Transportation methods and related infrastructure aim to maximize efficiency in an environmentally responsible fashion. The study also offers a description of the process by which inventory was decreased from 2006 to 2008 at Audi. This process was successfully managed using requirements and measures such as activitybased costing.

In the fourth section, the paper discusses the local government's role in economic development by means of industrial infrastructure and taxation. Until 2013, Audi enjoyed a special tax status. This did not mean, however, that the company was paying less tax. Audi also supports public institutions. The last section describes the company's corporate social responsibility activities highlighting the positive effects of Audi's presence. Without being overly optimistic, the study also recognizes critical issues and uncertainties regarding long-term regional development. These points are summarized at the end of the five main sections of the paper.

\section{Bevezetés}

Egy térség gazdasági szerkezete a szakirodalomban sikerfaktorként definiált tényező, melynek alaptényezői közé tartozik a külföldi befektetők jelenléte és a kutatás-fejlesztés (Lengyel 2010). A területi tőke összetételében a magán állótőke és a tulajdonosi hálózatok objektíven mérhető tárgyi javak, melyek hozzájárulnak ahhoz, hogy a terület értéke is mérhetővé váljon (Camagni 2009). Győr városának fontos feladata a gazdaság történelmi múltra építő működésének fejlesztése. A tanulmányban az Audi Hungaria Motor Kft.-re vonatkozó vállalati és Győr városával kapcsolatos területi statisztikai adatokat elemzek. A külföldi működő tőke jelenléte a térségben elsősorban az ipar tartós életképességét biztosítja. Ennek egyik alapvető feltétele azonban a helyi gazdaságba és társadalomba való sikeres beágyazódás. A tanulmány célja a helyzetleírás mellett azon jelenségek összegyüjtése, melyek későbbi elemzést igényelnek a jövőbeli dinamikus területi fejlődés megvalósítása érdekében. 


\section{Az Audi Hungaria Motor Kft. bemutatása}

Az Audi Hungaria Motor Kft. győri gyárában fejleszt és gyárt motorokat az Audi AG és a Volkswagen-csoport más telephelyei számára. Az ingolstadti gyárral együttmüködve itt készül az Audi TT Coupé és Roadster, valamint az A3 Cabriolet. Az Audi 1993-as alapítása óta Magyarország egyik legnagyobb exportőrévé és egyik legtőkeerősebb vállalatává nőtt. A vállalat alapítási törzstőkéje 100 millió euró. Tevékenységi területe: motorok és motorkomponensek gyártása, gépjármű- és szerszámgépgyártás, műszaki fejlesztés. (Az itt tervezett és gyártott szerszámgépek lehetővé teszik a karosszéria-részegységek geometriailag pontos egymáshoz illesztését a legmodernebb technológiával. A konszernen belül szinte az összes modellhez - Audi, Porsche, Seat, Škoda, Volkswagen - a győri Audiban készítenek szerszámgépeket.)

Az 1800-as évek végén Németországban sorozatosan jöttek létre a személygépkocsigyárak, 1909-ben pedig megalakult az Audi. Ez később az 1885-ben alakult Wandererrel, az 1899-ben alapított Horchhal és az 1907-ben alapult DKW-val egyesült, és a négy vállalat 1932-ben a motoros járműveket gyártó Auto Union AG néven jelent meg a piacon. 1949-től a vállalat Auto Union GmbH néven folytatta működését Ingolstadtban. A következő fontos év 1969 volt, amikor az 1873-ban alapított neckarsulmi NSU utódvállalatával, az NSU Motorenwerke AG-vel való egyesítés következtében neckarsulmi székhellyel megalakult az Audi NSU Auto Union AG. 1985-től a részvénytársaság Audi AG néven, ingolstadti központtal folytatja működését. Ma az Audi a Volkswagen-konszern tagjaként az egész világot behálózza leányvállalataival, Japántól Brazíliáig, Olaszországtól Ausztráliáig.

\section{Az Audi letelepedési folyamata}

Győr hosszú gazdasági múltjának is köszönhető, hogy a rendszerváltás után jelentős külföldi befektetői réteg telepedett le a városban. Olyan vállalkozási tevékenységek indultak el sikeresen, melyeknek nem volt hagyománya. A város - főként a későbbi Győri Ipari Park kialakításán keresztül - új iparágak befogadására is alkalmassá vált. A kiépített ipari környezet iránt a mai napig jelentős a külföldi tőke befektetői érdeklődése (GYMJVÖ 2008). Győr - a lakosság összetételét, ipari termelését, átlagkereseti szintjét tekintve - magyar viszonylatban a KSH 2011-es és 2012-es adatai alapján kiemelkedik.

Az Audi AG 1993-ban a Győri Ipari Park területén egy közművesített iparterületet és egy félig kész 100000 négyzetméteres csarnokot vásárolt meg a győri Rába Magyar Vagon- és Gépgyártól, és megalapította az Audi Hungaria Motor Kft.-t. Ezzel nemcsak az Audi nemzetközi versenyképességét biztosította, hanem meghatározó stratégiai telephelyet hozott létre Magyarországon. A telephely jelentősége azóta is folyamatosan nő Magyarországon és a világban 
egyaránt: ma már szinte az Audi járműveinek teljes motorválasztéka Győrből származik. A motorgyár 1994-es megnyitásával kezdődött a négyhengeres, ötszelepes Otto-motorok gyártása. Az 1996-os bővítés során a négyhengeres motorszerelde és a vizsgálópadok készültek el, emellett a mechanikus megmunkáló üzembe helyezésével az alumínium forgattyúházak (alumíniumötvözetből vagy öntöttvasból készülő motoralkatrész) gyártása indult el. A hat- és nyolcszelepes motorok sorozatgyártása 1997-ben kezdődött. Egy évvel később vette kezdetét az Audi TT Coupé gépkocsik összeszerelése, melyet 1999-ben a TT Roadster követett. A 2000-es évek elejének beruházásai indították el a műszaki fejlesztést és a szerszámgyártást. A motorfejlesztő központot 2001-ben avatták fel, amely sorozatgyártást támogató fejlesztési tevékenységével segíti az Audi motorgyártási folyamatait. A központban motorkonstrukciós részleg, motorpróbára alkalmas eszközök és műhelyek találhatók. 2005-ben felavatták az Audi szerszámgyárát, mely 40 millió eurós beruházással jött létre. Ez a présüzemhez szükséges szerszámokat és a karosszériagyártáshoz szükséges üzemi eszközöket gyártja és tervezi. Emellett kisszériás gyártásban oldalfalelemeket, motorháztetőt, csomagtartótetőt, sárhányót és ajtót gyárt Audi-modellek számára. 2007 az új technológiájú motorok gyártásának kezdete. Ugyanebben az évben az ingolstadti gyárral együttműködve, közös gyártási folyamatban megkezdődik az Audi új modellje, az A3 Cabriolet gyártása. Ezt követően, 2008-ban indul a tizenkét hengeres TDI motorok gyártása. A kísérleti motorgyártó központ 2010-ben nyitotta meg kapuit, s ekkor jelentették be a teljes jármügyártási folyamatot magába foglaló gyárbővítést is. 2012 júniusában megkezdődött az új, 1,2 és 1,4 literes négyhengeres Otto-motorok szériagyártása (Audi 2013).

Az Audi több sikert is elért. 2011 januárjában újabb Audi-modell gyártása indult meg. Az A3 RS változata a negyedik modell, amely a győri gyárban készül. Februárban a kormány kiemelt beruházássá nyilvánította az Audi bővítését, amely közvetlenül 1800 munkahelyet hoz létre, közvetve pedig tizenötezret. Ez a szám a város népességével összevetve jelentős hatást gyakorolhat Győr fejlődési folyamataira. Március elején a vállalat harmadik alkalommal kapta meg az ország legvonzóbb vállalata címet. (A címet 33000 interjúalannyal készített felmérés alapján az Aon Hewitt és az AIESEC adta.) Áprilisban 11,2 milliárd forint állami támogatást kapott a gyár bővítése. Ugyanebben a hónapban adták át a Széchenyi István Egyetem Audi Hungaria Belső Égésű Motorok Tanszékének új épületét, amely technológiai bővítéssel gazdagította az intézményt. Ezzel egy időben az Audi kísérleti motorgyártó központját is bővítette. Júliusban az Audi-bővítéseket kiegészítették egy présüzemmel, ezzel a tervezett 1800 közvetlen munkahely 300 munkahellyel növekedett. A vállalat szeptemberben már 7000 embert alkalmazott (MGSZ 2012).

A gyártási volumenben a következő fontos pontokat érte el a vállalat:

- 2005 júniusában elkészült a tízmilliomodik győri motor, amelyet egy speciálisan kialakított rendőrségi Audi TT-be szereltek be;

- 2011 áprilisában elkészült a húszmilliomodik motor; 
- 2012 júniusában elkészült a kétmilliomodik V6 TDI motor;

- 2012 decemberében elkészült az ötszázezredik nyolchengeres motor.

Összefoglalva, az 1994-es gyárnyitás óta az Audi folyamatos bővülésen megy keresztül, amellyel jelentősen hozzájárul Győr és térségének fejlődéséhez.

\section{A vállalat jelenlétének munkaerőre gyakorolt hatása}

A munkaerőre gyakorolt hatást három szempontból lehet vizsgálni. Az első szempont a helyi munkaerőre gyakorolt hatás. Győr mint megyeszékhely demográfiai vizsgálatánál a lakossági adatok közül a tanulmányban a munkaképes korú lakosság és a vállalkozások viszonyát vizsgálom az Audi letelepedése óta. A munkaképes lakosság arányát elemezve érdemes Nyugat-Magyarországra tekinteni, ahol feltételezhető a munkaerő nagyobb arányú letelepedése, többek között a határon túli munkalehetőség miatt. 2009-ben Győr-Moson-Sopron megyében 50,4\% volt a munkaképes korú népesség aránya. Ha a mutató időbeli alakulását a korábbi években (1996-2008) összehasonlítjuk a többi megyei adattal, Győr-Moson-Sopron megye minden évben a magasabb arányú megyék csoportjába tartozott, 56-57\%-os szinttel (TeIR 2013). A munkaképes korú lakosság aránya a többi megyéhez képest csak némileg magasabb Győr-Moson-Sopron megyében. A 2008 előtti időszak adatainak vizsgálata pedig azt mutatja, hogy a munkaképes korú népesség aránya az Audi bővülése ellenére nagyjából stagnált, de a válság hatására 2008 után csökkenni kezdett.

Ebből következik, hogy a 131267 fő lakosú Győrben a gyár bővítéséhez szükséges szakmai tudással rendelkező munkaerő toborzása 2011 óta jelentős erőfeszítést igényel. A 2011-es bővítés az Audi által keresett, főként szakképzett munkaerőre elszívó hatást gyakorolt a régióban. A munkaerő szempontjából időleges szakemberhiány volt megfigyelhető, a vállalat szemszögéből az egyre távolabb elérhető munkaerő vonzása járulékos költségekkel járhat. A térségben az Audi magas bérszínvonalon müködik, így a kisebb cégek munkaerejét is vonzza. A Németországból érkezett munkaerő olyan arányokat ért el a helyi munkaerő-állományban, amelynél az integráció intézményesített formái szükségessé váltak. Ezek az intézmények (iskola, akadémia) közvetlenül szolgálják a Győrbe érkezett német munkaerő családtagjait. Mivel ezek az intézményrendszerben különálló szervként működnek (elsődlegesen a beáramló külföldi munkaerő részére), a teljes integráció és az ezt serkentő lépések szükségessége merülhet fel a város számára. A menedzsmentelit integrációjával kapcsolatban ugyancsak sok kérdés merülhet fel, melyek a helyi fejlesztések részét képezhetik.

A második szempont a külföldi munkaerő vonzásának mértéke és módja. Az Audinál egyértelműen számolni kell a külföldi munkaerő-szükséglettel. A német nyelvismeret a hazai munkaerő-kínálatban rendelkezésre áll. A munkaerő-közvetítő portálok alapján érzékelhető a vállalat cseh és szlovák nyelven 
beszélő dolgozóigénye, amelyet inkább külföldről fedeznek, egyrészt Szlovákia közelsége miatt, másrészt mert a szlovák nyelv nem tipikus tanított nyelv Magyarországon. Míg a német munkaerőről több információ áll rendelkezésre, megvizsgálható a szlovák nyelvű munkaerő ingázási vagy helyben maradási aránya. A külföldről rövidebb vagy hosszabb időre vonzott munkaerő fogyasztási szokásai alakítják a helyi fogyasztási szokásokat, ez alapján terveznek a helyi termelők és szolgáltatók.

A harmadik szempont a helyi üzleti szféra véleménye az Audi munkaerőre gyakorolt hatásáról. Hogyan értékelik az Audi szerepét a kisebb helyi iparvállalatok? Milyen arányban tekintenek rá szövetségesként és hányan látják úgy, hogy helyi munkaerőt szív el? A legfontosabb hatás, hogy a kisebb vállalkozásoknál az Audi munkaerő-elszívása béremelést kényszerít ki.

\section{Logisztika és beszállítói hálózat}

A beszerzési és elosztási logisztika az Audinál külön központban müködik. A fejezet célja az Audi logisztikában felépített szigorú követelményrendszerének és az ezzel járó, beszállítókat érintő hatásoknak a bemutatása. A logisztika a vállalaton belül három fö részből áll:

- motorlogisztika: a különböző motorok programtervezése és elosztása, előszéria-logisztika, CKD és OT logisztika (magyarázatukat lásd később),

- jármülogisztika,

- vállalatlogisztika: transzportlogisztika, tervezés, operatív logisztika.

A motorlogisztika a motorgyártást szolgálja. A CKD (completely knocked down) logisztika a tengerentúli vevők kiszolgálásával foglalkozik, a teljesen szétszerelt állapotban rendelt motorok szállítása tartozik ide. Az OT (Original Teile) logisztika a régebbi járműmodellekhez kapcsolódó alkatrészek szállítását látja el. Az előszéria-logisztika feladata a termékek szériagyártásba kerülése előtt a vevői minőségi igényeknek megfelelő feltételek biztosítása. A programtervezés és a motordiszpozíció egymással szorosan összefüggő területek, amelyeket 2007 végén motorszegmensenként vontak össze. A programtervezők a vevői igények alapján összeállítják a gyártási programot, a diszponensek a termeléshez szükséges alkatrészeket és anyagokat rendelik meg, biztosítják a folyamatos alkatrészellátást. A motorlogisztikán belül négy logisztikai terület létezik: az R4 Otto-motorok, az R4 dízelmotorok, a V6 motorok, valamint a V8, V10 és V12 motorok (Bödör 2007).

Az Audi a különböző készletoptimalizációs módszereket tudatosan, stratégiai szinten, a vállalat életébe beépítve alkalmazza, ezek a módszerek megjelennek a felsorolt logisztikai területeken. A motorlogisztika mint a vállalat életében legrégebbi logisztikai terület számos készletoptimalizációs megoldást tartalmaz. A készletcsökkentés fóbb szakaszait az 1. táblázat mutatja. 
1. táblázat: A készletcsökkentés bevezetése az Audinál Steps of reducing inventory at Audi

\begin{tabular}{ll}
\hline \multicolumn{1}{c|}{$E v$} & \multicolumn{1}{c}{ Lépés } \\
\hline 2006 & $\begin{array}{l}\text { Az Audi központi menedzsmentje döntést hoz a készletek csökkentésének } \\
\text { szükségességéröl, a cél 50\%-os készletcsökkentés egy készletkövetést és } \\
\text {-optimalizálást szolgáló projekt révén. }\end{array}$ \\
\hline 2007 év vége & $\begin{array}{l}\text { Sikerül teljesíteni a lépcsőzetesen előírt célokat. 2005 és } 2007 \text { között az éves átlagos } \\
\text { készletfedezeti idő kevesebb mint a felére csökken.* }\end{array}$ \\
\hline 2007-től & $\begin{array}{l}\text { A projekt lezárását követően a vállalat kielemezte a csökkenéshez legjobban } \\
\text { hozzájáruló tényezőket (ABC-analízis**, szállítási idők elemzése, beszállítók } \\
\text { kontrollálása, a termelési igény és a szállítási idők összehangolása, csomagolási } \\
\text { egységek gyártás szerinti beosztása, túlszállítási szankció). }\end{array}$ \\
\hline 2008-tól & $\begin{array}{l}\text { A folyamatosan alkalmazott, központilag irányított és felügyelt, szemléletmód- } \\
\text { formáló logisztikai irányítás rendszeresen alkalmazza az első készletcsökkentő } \\
\text { projekt eszközeit. }\end{array}$ \\
\hline
\end{tabular}

* 2005-ben a motordiszpozíció területén az éves átlagos készletfedezeti idő 6,34 munkanap volt. Ez azt jelenti, hogy az éves átlagos raktárkészlet 6,34 napi termelés ellátásához volt elegendö. A projekt indulásakor meghatározott első célérték 4,65 nap volt, melyet a 2006. évi leltárig kellett elérni, majd az érték tovább csökkent, a 2007. év végére 3,1 nap lett. Az elsö évre 20\%-os értékcsökkenést tüztek ki, ebböl 17\% teljesült, a másodikéves cél pedig további $30 \%$ volt, melyet 2007 végére teljes mértékben sikerült teljesíteni.

** Az ABC-elemzés a vállalat által beszerzett anyagok és alkatrészek rendszerezésére szolgál. Célja az értékes alkatrészek kimutatása és az egész anyagbázishoz viszonyított mennyiségi arányuk megállapítása. Az Audinál alkalmazott $A B C$-analizis a belső vállalatirányitási rendszer adatai segítségével, az egységár és az igény szorzata alapján csoportokba osztja az alkatrészeket.

Forrás: saját szerkesztés, internetes adatok és interjúk alapján.

\section{Az AUDI beszállítóinak hatása a helyi vállalkozásokra}

Az 1. ábrán az Audi logisztikájával kapcsolatos struktúrák, vagyis a telephelyek és a beszállítók közötti szállítási folyamatok láthatók. Az Audi különböző szállítási feltételeket alkalmaz nagyvállalati pozíciója révén (pl. a szállítás módjától és hosszától függetlenül az Audi telephelyére való érkezés időpontjának meghatározása). A szállítási módok rendszerezése és a felmerülő hibák menedzselése folyamatos. A szállítási módokat három csoportra oszthatjuk:

- Közvetlen szállítás: vagy tisztán közúti forgalom, vagy (a tengerentúli beszállítók esetében) hajóval történő szállítás, majd a kikötőből a szállítmány közúti továbbítása.

- Közvetett szállítás: az árut az adott területeken illetékes szállítmányozásszervező gyüjti be és juttatja el az ingolstadti konszolidációs raktárba, ahonnan az Audi szervezésével, részletesen kidolgozott rendszer alapján, a környezettudatossági szempontok figyelembevételével leginkább vasúton történik a szállítás. Az Audi a győri vasútvonalon saját pályaudvarral és árukezelő rendszerrel rendelkezik. Emellett különleges 
1. ábra: Az Audi és beszállító partnerei

Audi and its suppliers

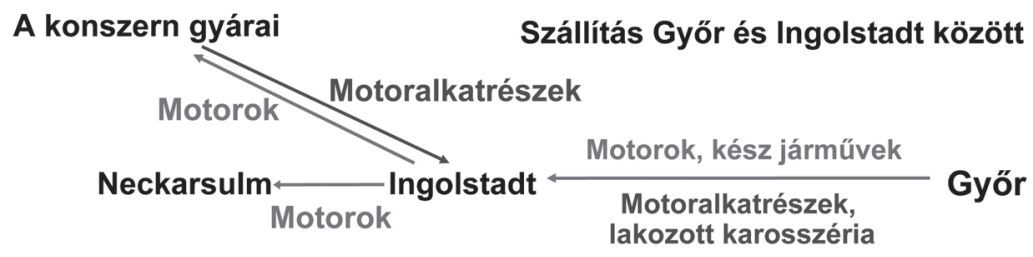

Forrás: Horváth 2011, 22.

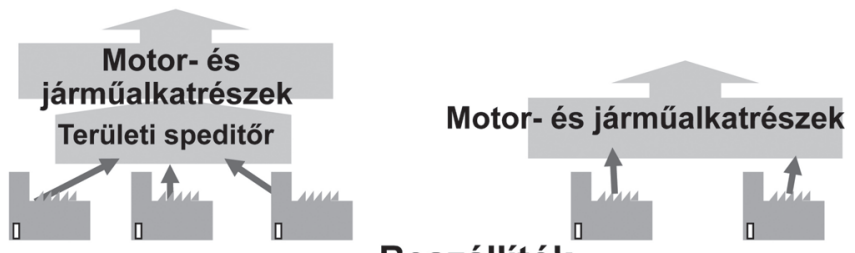

Beszállítók

esetekben közúti szállítás és a Győr mellett elhelyezkedő péri repülőtér szállítási kapacitása is használható.

- Körszállítás: az Audi és beszállítója közötti keretszerződés alapján, közúton történő szállítás, amely a mérethatékonyságot aknázhatja ki abban az esetben, ha a szállítóautók a megengedett maximumon terheltek.

Az Audi sikeresen elvégezte a szükséges készletcsökkentő lépéseket. Annak érdekében, hogy hatékonyan működjön a termelés, folyamatos és termelési volumenhez igazított készletezést végez. Ehhez komplex vállalatirányítási eszközöket és szabályrendszert alkalmaz. A termeléshez igazított, készletoptimalizálást ellátó szállítás infrastrukturális feltételei kiépítettek.

A következő vizsgálati szempont a beszállítók összetétele. A magyar tulajdonú beszállítók aránya mindössze $4 \%$, és bár arányuk növekedett, még mindig csak Tier3 szinten vannak. Az 58\%-ban német tulajdonban lévő beszállítók hatékonyan alkalmazzák a beszállítói módszereket, illetve leányvállalatok idetelepedésével hidalták át a távolságot. A magyar beszállítók aránya hosszú távú megfigyelést igényel annak érdekében, hogy gazdaságpolitikai következtetéseket tudjunk levonni.

E körülmények között érdemes megfigyelni a vállalat beszállítói láncainak hosszát, valamint azt, hogy a jelenlegi OEM (original equipment manufacturer) beszállítók életpályája hogyan alakult. Érdemes azt megvizsgálni, hogy az Audi első számú beszállítói a Volkswagen-konszern többi tagjának is szállítanak-e, és ha igen, akkor mióta, milyen mértékben. Ezt átlátva lehet találni olyan alkatrészeket, melyek helybeli gyártása felgyorsíthatja az Audi gyártási folyamatait a külföldi beszállításhoz képest. A kérdéskör fontos azon magyar tulajdonú vállalatok számára is, melyeknek célja a beszállítói körbe való belépés, illetve a feljebb lépés. A járműipar Kelet-Közép-Európában hosszú múltra tekint vissza 
(Rechnitzer, Smahó 2012). A kiépült beszállítói hálózatban a magyar vállalkozásoknak periferikus helyzete van, a szállítási infrastruktúra és a teljes beszállítói hálózat elemzésének hiánya a beágyazódás akadályaként is értelmezhető. Ezzel szemben egy ekkora vállalat beszállítói hálózata innovációs hatással lehet a helyi vállalkozói környezetre. Dinamikus ipari környezetben nagyobb esély van új vállalkozások, kiegészítő szolgáltatások szerveződésére, spinoff esetek előfordulására.

\section{Az önkormányzat gazdaságfejlesztő szerepe}

Győrben elsődleges cél egy erős, több lábon álló, versenyképes gazdaság kialakítása és megtartása. Győrben meghatározó az Audi jelenléte, a városnak kedvező környezetet kell biztosítania. Gondoskodnia kell a vállalkozások megközelíthetőségéről és a működés feltételeinek kialakításáról. A Győri Ipari Park 1992 óta biztosít magas szintű infrastruktúrát nagybefektetők és kisebb vállalkozások számára. A stratégiailag tudatosan, a közlekedési fővonalak közelében elhelyezett, alapítása óta bővülő terület olyan üzleti környezetet kínál, amely a stabil működés biztonságát és az üzleti fejlődés lehetőségét nyújtja a cégeknek. A Győri Nemzetközi Ipari Park Kft. Győr Megyei Jogú Város Önkormányzatának tulajdonában lévő cég, amely hosszú ideje biztosítja az alábbi szolgáltatásokat:

- közvetlen autópálya- és vasúti kapcsolat;

- a tulajdonviszonyok rendszerezése;

- a talajszennyezettség mérése;

- a közműellátottság biztosítása;

- a helyhatósággal kapcsolatos ügyintézés;

- a letelepedés kezelése, a letelepedés utáni működést támogató tevékenységek.

Az Audi jelenléte az ipari tevékenységek összetételén látszik. Az ipari park az elmúlt időszakban lehetőséget biztosított jármüipari és más iparági szereplők letelepedésére. A város által folyamatosan fejlesztett 191 hektárnyi területen prioritás a megfelelő környezet megteremtése kis- és középvállalkozások számára annak érdekében, hogy a járműipar beszállítói hálózata fejlődhessen. Az adózási környezet ismérve, hogy Győr városa 2014 januárjától 10\%-kal csökkentette a helyi iparüzési adót (GYMJVÖ 2013); az ipari körzetet dominánsan alakító vállalatként az Auditól származik az iparűzési adó döntő része. 2013. decemberig a város lehetőséget biztosított a győri székhelyű vállalkozások részére, hogy befizetett iparüzési adójuk bizonyos százaléka felett rendelkezzenek, ha ugyanarra a célra lekötik költségeik bizonyos százalékát. Az Audi élt ezzel a lehetőséggel: 2013 decemberéig a vállalat által befizetett adó 4\%-ából kulturális, sport- és művészeti tevékenységeket fejlesztett a város. Ezért cserébe az Audi azt vállalta, hogy az általa választott tevékenységre társadalmi felelősségvállalás formájában további, a 4\%-kal megegyező összeget fordít. (GYMJVK 2013) 


\section{Társadalmi felelősségvállalás a vállalatnál}

Az előzőekben bemutatott megoldás az iparűzési adó felhasználásával egyfajta önállóságot nyújtott a vállalatoknak. A fejlesztett tevékenységek szempontjából pedig a koncepció pozitív módon járulhat hozzá a támogatások kiszámíthatóbbá, átláthatóbbá tételéhez. A továbbiakban a támogatott részterületeket mutatom be.

Amellett, hogy a vállalat sportesemények rendszeres támogatója, 2006 óta névadó főszponzora a Győri ETO kézilabdaklub női csapatának és a győri nemzetközi utánpótlástornának. 2011 óta kiemelt támogatója a Győri ETO futballklubnak. 2013-ban arany fokozatú támogatóként járult hozzá a Magyar Olimpiai Bizottság tevékenységéhez.

A cég a kulturális események rendszeres támogatásán túl az évente megrendezett városi nyárzáró koncert fellépőinek főtámogatója 2002 óta. Szintén 2002-től a világszerte ismert Győri Balett főtámogatója.

Az Audi felismerte azt a tényt, hogy az egyetemi kooperáció elsődleges a szakember-utánpótlás szempontjából, hiszen Győr területének humán tőkéje és az Audi tőkéjének értéke is növekedhet ezáltal. A 2011-es üzleti jelentés kimondja, hogy a „jövő kulcsa a képzés” (Audi 2012). A győri Széchenyi István Egyetem Műszaki Tudományi Karán az Audi Hungariának négy tanszéke működik: az Anyagtudományi és Technológiai Tanszék, a Belső Égésű Motorok Tanszék, a Járműgyártási Tanszék, valamint 2013-tól a Jármüfejlesztési Tanszék. Ezek együttesen alkotják az Audi Hungaria Jármümérnöki Tanszékcsoportot, így erősítik az Audi-konszern és az Audi Hungaria jelenlétét a Széchenyi Egyetemen (Audi 2013). Az Audi Hungaria Iskola 2010. szeptember 1-jén kezdte meg müködését. A magyar tanulók az első osztálytól két tanítási nyelvű oktatási program alapján, magas színvonalon sajátítják el a német nyelvet. A német gyermekek németországi tanterv szerint tanulnak, ami biztosítja, hogy hazatérésük után minden nehézség nélkül bekapcsolódjanak a németországi oktatásba. Az integráció kérdése tehát ebben az intézményben kulcsfontosságot kap. Az Audi és a Széchenyi István Egyetem 2008-ra visszanyúló együttműködéséből közvetlenül profitál az Audi: már születtek olyan kutatási eredmények, melyek az ingolstadti központnak is hasznossá válhatnak. Vagyis a kutatás-fejlesztési tevékenység Győrben egy kooperatív tevékenység hasznos eredménye (SZE 2013). E kutatásfejlesztési tevékenység nem kiemelkedő mértékủ a vállalat teljes fejlesztéspolitikájában, helyi vonatkozásban viszont a közvetlen szponzoráció mértéke magas szintű. A Mobilis egy olyan, főként a járműiparra és a közlekedésre fókuszáló tudományos játszóház, amely az interaktív játékok, a rendhagyó természettudományos bemutatók révén megkedvelteti a müszaki és természettudományokat a látogatókkal, s a fiatal generáció e benyomások alapján fogékonyabbá válik e területekre, ami segítheti pályaválasztásukat is (Mobilis 2013). 


\section{Összegzés}

A tanulmány leíró jelleggel mutatta be azt a környezetet és időtávot, amelybe az Audi mint globális vállalat beilleszkedett, felsorolta a letelepedés mérföldköveit, intézményi hatásait. Az 1993-ban letelepedett vállalat máig perspektívát lát Győr városában. Ezt alátámasztja a 2011-es bővítés és a vállalat kommunikációs anyagaiban a városi értékek kiemelése. A helyi munkaerö-állományra, a helyi bérköltségekre, a társadalmi integrációs folyamatokra, a vállalkozásokra, a kis- és középvállalati szektorra, az adózási rendszerre és az oktatásra gyakorolt hatások kritikus és a helyi gazdaságfejlesztés részéről különleges figyelmet igénylő területek. Mivel a vállalat egyértelmű főszereplője az ipari körzetnek, ezek a jelenségek a regionális gazdaságra egyedi módon hatnak. A város figyelembe veszi ezt, az együttműködés különösen az infrastruktúra fenntartásában és fejlesztésében, valamint a közös, kutatás-fejlesztéshez köthető célok elérésében valósul meg.

\section{Irodalom}

Audi (2012): Az Audi Hungaria Motor Kft. éves jelentése, 2011.

Audi (2013): http://www.audia3limousine.hu/?utm_campaign=FB_POR034_2013_Audi_A3_Limousine_0923_1020\&utm_source=prcikk\&utm_medium=\%2Ffn24\%2FPRcikk\%2Fprcikk (Letöltés: 2013. november 22.)

Bödör E. (2007): Az Audi Hungária Motor Kft. Magyarországon. Szakdolgozat. Budapesti Gazdasági Főiskola, Budapest

Camagni, R. (2009): Territorial capital and regional development. In: Capello, R., Nijkamp, P. (eds.): Handbook of regional growth and development theories. Edward Elgar, Northampton, 118-132.

GYMJVK [Győr Megyei Jogú Város Közgyűlése] (2013): A helyi iparüzési adó meghatározott részének célirányos felhasználásáról szóló 8/2000. (III. 10.) Ök. rendelet.

GYMJVÖ [Győr Megyei Jogú Város Önkormányzata] (2008): Győr Megyei Jogú Város középtávú integrált városfejlesztési stratégiája. Győr

GYMJVÖ [Győr Megyei Jogú Város Önkormányzata] (2013): Elöterjesztés a helyi iparüzési adóról szóló 34/2010. (XI. 26.) GYMJVÖ rendelet módosítására, valamint 8/2000. (III. 10.) Ök. rendelet hatályon kívül helyezésére.

Horváth G. (2011): Handout - Egy motorgyár létesitése. Széchenyi István Egyetem, Győr http://www.sze.hu/ kardos/AUDI2011/Handout\%20\%20Egy\%20motorgy\%E1r\%20l\%E9tes\%EDt \%E9se_SZE_20110920.pdf (Letöltés: 2013. november 20.)

Lengyel I. (2010): Regionális gazdaságfejlesztés. Versenyképesség, klaszterek és alulról szerveződő stratégiák. Akadémiai Kiadó, Budapest

MGSZ [Magyar Gépjármű Szövetség] (2012): 2011 csúcsév volt a magyar jármügyártás történetében: beruházások, fejlesztések, munkahelyteremtés. Magyar Gépjárműipari Szövetség, Budapest http://www.gepjarmuipar.hu/hirek/autoipari-hirek/2011-csucsev-volt-a-magyar-jarmugyartastorteneteben-beruhazasok-fejlesztesek-munkahelyteremtes/141/ (Letöltés: 2013. május 5.)

Mobilis (2013): http://mobilis.gyor.hu/mobilisrol/a-kozpontrol (Letöltés: 2013. május 5.)

Rechnitzer J., Smahó M. (2012): Vehicle industry and competitiveness of regions in Central and Eastern Europe. Széchenyi István Egyetem, Universitas-Győr Nonprofit Kft, Győr

SZE (2013): http://uni.sze.hu/dobog-a-szengine-gyori-egyetemistak-versenymotort-epitettek (Letöltés: 2013. szeptember 10.)

TeIR (2013): Idősoros elemző. https://www.teir.hu/idosor/index.html (Letöltés: 2013. november 26.) 